\title{
Systemic inflammation in malignant pleural mesothelioma: Is neutrophyl-to-lymphocyte ratio a prognostic index?
}

Felice Mucilli $^{1 *}$, Pierpaolo Camplese ${ }^{1}$, Luigi Guetti ${ }^{1}$, Barbara Maggi ${ }^{1}$, Marco Prioletta ${ }^{1}$, Mirko Barone ${ }^{1}$, Antonia Rizzuto ${ }^{2}$ and Rosario Sacco $^{2}$

${ }^{1}$ Department of General and Thoracic Surgery, University “G. d'Annunzio “-Chieti, Italy

${ }^{2}$ Department of Medical and Surgical Sciences, University “Magna Graecia”- Catanzaro, Italy

\begin{abstract}
Malignant Pleural Mesothelioma (MPM) is an aggressive, asbestos-related tumor that arises from the mesothelium. It is a neoplasm with an increasing incidence with a poor and a dismal prognosis. Inflammation plays a crucial role in the initiation and tumor progression. In addition, the history of MPM is characterized by symptoms referred to increased inflammatory responses such as fever, sweating and loss of weight. Recent studies have identified the neutrophil-to-lymphocyte ratio (NLR) as a feaseble and simple marker of systemic inflammation. The Authors report a retrospective study in 54 patients with malignant pleural mesothelioma (MPM). MPM patients were more likely to be male (75.9\% versus $24.1 \%)$ with a median age of 67 years. The epithelial histotype was predominant (77.8\%) compared to the biphasic (11.1\%), sarcomatous (9.5\%) and desmoplastic (1.9\%) ones. Neutrophil-to-Lymphocite ratio (NLR) was assessed at diagnosis with a mean value of 4.31. The aim of the study was to test bivariate correlations between independent factors (age, sex, histology, NLR, lymphocyte count, lymph node involvement) and the overall survival of the population under investigation. The median overall survival (OS) in the general population included in the study was 13 months. Median Disease Free Interval (DFI) was 3 months. Patients with the epithelial histotype survived significantly longer than those presenting with sarcomatoid, biphasic or desmoplastic subtypes (15 months versus 2,8 and 10 months respectively; $\mathrm{p}<0.001$ ). Patients with NLR<3 showed a median overall survival of 22 months, while $3<\mathrm{NLR}<5$ and NLR $>5$ ones had a poorer survival rate (12 and 8 months respectively). There was evidenced of a strong correlation between patients with inflammation index less than three and overall survival $(\mathrm{p}<0.001)$. The Neutrophil-to-Lymphocyte Ratio (NLR) can be an independent, easily reproducibile and comparable prognostic index in patients with malignant pleural mesothelioma.
\end{abstract}

\begin{abstract}
Abbreviations: MPM: Malignant Pleural Mesothelioma, NLR: Neutrophil to Lymphocyte Ratio, OS: Overall Survival, DFI: Disease Free Interval
\end{abstract}

\section{Introduction}

Malignant Pleural Mesothelioma (MPM) is an aggressive, asbestosrelated tumor that arises from the mesothelium [1]. It is a neoplasm with an increasing incidence [2]. Although numerous therapeutic options in patients with malignant pleural mesothelioma have been taken, the disease presents a poor and dismal prognosis [3] with a survival rates average 9-12 months [4-8].

Numerous studies report evidences about factors associated with prolonged survival and their impact on the disease's evolution. These factors include demographic characteristics (eg. sex, age), analytes (absolute value of leukocytes, lymphocytes) and tumor characteristics (histology). In this regard, the European Organisation for Research and Treatment of Cancer (EORTC) and the Cancer and Leukemia Group B have drafted two prognostic indeces for patients with MPM [9-12]. Inflammation plays a crucial role in the initiation and tumor progression [13]. In addition, the history of MPM is characterized by symptoms referred to an increased inflammatory response such as fever, sweating and loss of weight [14-17]. As mentioned, the indices of inflammation may play a prognostic role in patients with malignant pleural mesothelioma. Recent studies have identified the neutrophilto-lymphocyte ratio (NLR) as a feaseble and simple marker of systemic inflammation [18-22]. However, avaible data are conflicting [23,24].

\section{Patients and methods}

\section{Study and analysis}

We report a retrospective study in patients with malignant pleural mesothelioma (MPM) conducted over the last decade (2004-2015). We proceeded to a descriptive and observational demographic study. In the second part of the analysis, survival rates were tested in the general population and in selected cohorts (NLR value, histology, lymph node involvement, therapeutic strategy). Finally, a bivariate analysis was carried out to identify positive independent prognostic factors in the population.

The analysis of survival and related ratios was performed by Kaplan and Meier's method, while in the bivariate analysis values of $\mathrm{p}<0.005$ were considered significant.

\section{Patient characteristics}

Data on 54 patients with MPM, admitted consecutively to our Institution from 2004 to 2015, were collected. MPM patients were

Correspondence to: Felice Mucilli, Department of General and Thoracic Surgery, School of Specialization in Thoracic Surgery,University "G. d'Annunzio "-Chieti, Italy, Tel: +390871358288, +390871358289; E-mail: fmucilli@unich.it

Key words: malignant pleural mesothelioma, neutrophil to lymphycite ratio, overall survival

Received: November 28, 2015; Accepted: December 12, 2015; Published: December 15, 2015 
more likely to be male $(75.9 \%$ versus $24.1 \%)$ with a median age of 67 years [min. 46 - max. 85 (95\% CI 62.6 - 68.12) (Table 1).

The epithelial histotype was predominant $(77.8 \%)$ compared to the biphasic (11.1\%), sarcomatous (9.5\%) and desmoplastic (1.9\%) ones (Figure 1).

Of 54 patients, $53.7 \%$ were current or ex smokers, whereas $46.3 \%$ had no history of smoking. In $31.5 \%$ cases, a direct asbestos exposure (e.g. work or home) was assessed, in $16.7 \%$ an indirect one and in $51.9 \%$ patients no risk factors were recognized.

In total, $35.2 \%$ of patients received neoadjuvant chemotherapy. On immunohistochemistry, calretinin expression was showed in $87 \%$ of patients $(92.8 \%$ in epithelial, $66.6 \%$ in biphasic and $60 \%$ in sarcomatoid). All patients at diagnosis were staged according to the AJCC's staging system [25], with 59.3\% having an early stage (I-II stage) and $40.7 \%$ an advanced stage disease (III-IV stage).

Neutrophil-to-Lymphocite ratio (NLR) was assessed at diagnosis with a mean value of 4.31 [min. 0,9 - max. 16.5 (95\% CI 3.46-5.16)]. Clustering this series, $44.4 \%$ of patients had a NLR $<3,25.9 \%$ a $3<\mathrm{NLR}<5$ and $29.6 \%$ a NLR $>5$.

Table 1. Patient characteristics with malignant pleural mesothelioma, $2004-2015(\mathrm{n}=54)$.

\begin{tabular}{|c|c|c|}
\hline & Number (value) & $\%$ \\
\hline \multicolumn{3}{|l|}{ Demographic characteristics } \\
\hline 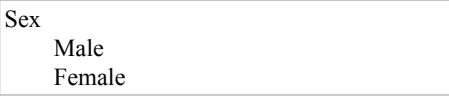 & $\begin{array}{l}41 \\
13\end{array}$ & $\begin{array}{l}75.9 \\
24.1\end{array}$ \\
\hline Median age & $\begin{array}{c}67 \\
(\min .46-\max .85)\end{array}$ & \\
\hline $\begin{array}{l}\text { Smoking } \\
\text { Current/ex smokers } \\
\text { No }\end{array}$ & $\begin{array}{l}29 \\
25\end{array}$ & $\begin{array}{l}53.7 \\
46.3\end{array}$ \\
\hline $\begin{array}{l}\text { Asbestos exposure } \\
\text { Direct } \\
\text { Indirect } \\
\text { No }\end{array}$ & $\begin{array}{c}17 \\
9 \\
28\end{array}$ & $\begin{array}{l}31.5 \\
16.7 \\
51.9\end{array}$ \\
\hline \multicolumn{3}{|l|}{ Clinical and pathological characteristics } \\
\hline $\begin{array}{l}\text { Calretinin expression } \\
\text { Epithelial } \\
\text { Biphasic } \\
\text { Sarcomatoid }\end{array}$ & 47 & $\begin{array}{c}87 \\
92.7 \\
66.6 \\
60.0\end{array}$ \\
\hline \begin{tabular}{|l} 
NLR \\
$\quad$ NLR $<3$ \\
$3<\mathrm{NLR}<5$ \\
$\quad \mathrm{NLR}>5$
\end{tabular} & $\begin{array}{l}24 \\
14 \\
16\end{array}$ & $\begin{array}{l}44.4 \\
25.9 \\
29.6\end{array}$ \\
\hline $\begin{array}{l}\text { Histotype } \\
\text { Epithelial } \\
\text { Biphasic } \\
\text { Sarcomatoid } \\
\text { Desmoplastic }\end{array}$ & $\begin{array}{l}42 \\
6 \\
5 \\
1\end{array}$ & $\begin{array}{c}77.8 \\
11.1 \\
9.5 \\
1.9\end{array}$ \\
\hline $\begin{array}{l}\text { Stage disease } \\
\text { Early stage ( IA-II) } \\
\text { Advanced stage (III-IV) }\end{array}$ & $\begin{array}{l}32 \\
22\end{array}$ & $\begin{array}{l}59.3 \\
40.7\end{array}$ \\
\hline \multicolumn{3}{|l|}{ Treatment characteristics } \\
\hline Neodjuvant chemotherapy & 19 & 35.2 \\
\hline $\begin{array}{l}\text { Radical Surgery } \\
\text { P/D } \\
\text { EPP } \\
E P P+H I T O C\end{array}$ & $\begin{array}{c}4 \\
25 \\
5\end{array}$ & $\begin{array}{c}7.4 \\
46.3 \\
7.4\end{array}$ \\
\hline $\begin{array}{l}\text { Palliative surgery } \\
\text { Pulmonary wedge resection/ lobectomy } \\
\text { Partial P/D } \\
\text { Pleural biopsies }\end{array}$ & $\begin{array}{c}2 \\
5 \\
18 \\
\end{array}$ & $\begin{array}{r}3.8 \\
9.3 \\
33.3\end{array}$ \\
\hline
\end{tabular}

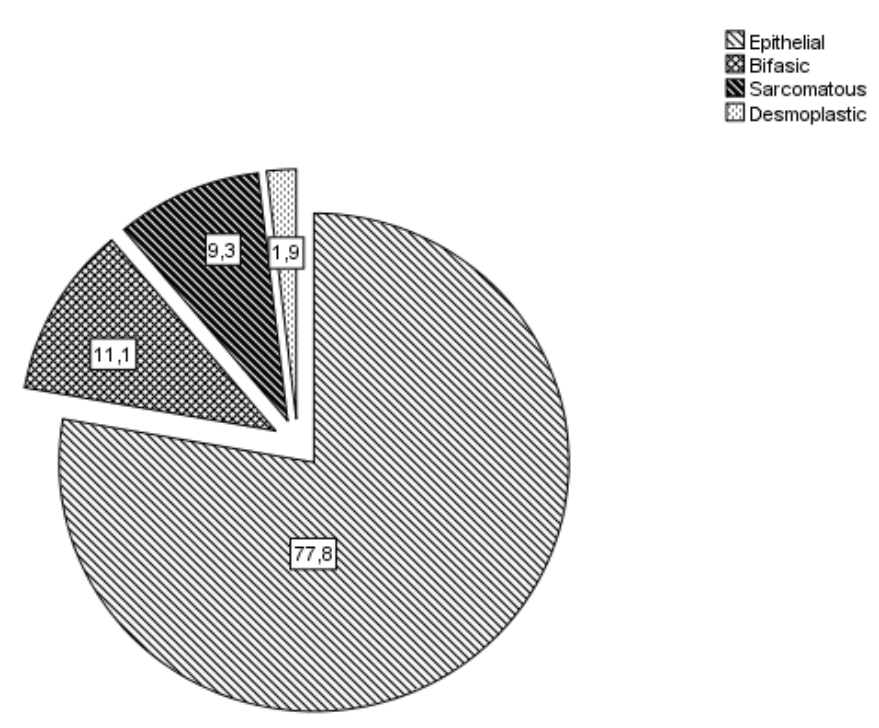

Figure 1. Malignant pleural mesothelioma histotypes.

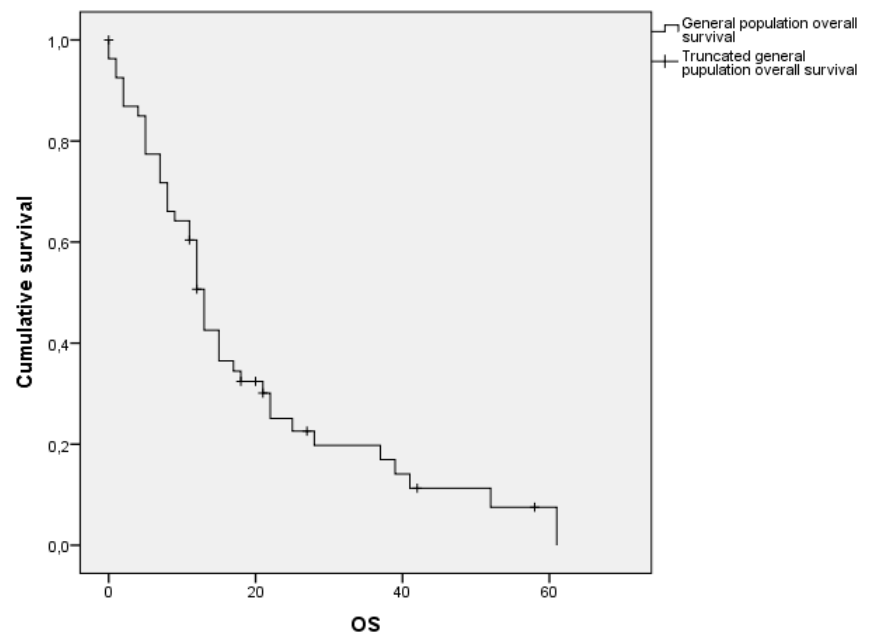

Figure 2. General population overall survival.

Radical surgery, in the form of extrapleural pneumonectomy, was undergone by $46.3 \%$ of the study population and, in $9.3 \%$ of them, a hyperthermic intrathoracic chemotherapy (HITOC) was offered. In 7.4\%, a Waller's extended pleurectomy and decortication was conducted. Remanents were referred to palliative surgery such as pulmonary wedge resections, partial pleurectomy/decortication and pleural biopsies. 30-day mortality was $5.6 \%$.

\section{Results}

The median overall survival (OS) in the general population included in the study was 13 months (95\% CI 11.48-14.51) (Figure 2 and Table 2). Median Disease Free Interval (DFI) was 3 months. Clustering this data according to the AJCC's Pleural Mesothelioma staging system, stage IA patients showed a median OS of 49 months, whereas stage IV ones was only of 5 months (Table 3 ).

Patients with the epithelial histotype survived significantly longer than those presenting with sarcomatoid, biphasic or desmoplastic 
Table 2. Malignant pleural mesothelioma: Overall survival and disease free survival. \begin{tabular}{|l|l}
\hline Population median overall survival (OS) & 13 months (95\% CI 11.48-14.51)
\end{tabular} Population median Disease Free Interval ( DFI) 3 months (95\% CI 0-9.64)

Table 3. Malignant Pleural Mesothelioma: bivariate analysis and correlations.

\begin{tabular}{|c|c|c|c|}
\hline & Median (OS) & $\begin{array}{c}\text { 95\% Confidence } \\
\text { Interval }\end{array}$ & $\mathbf{p}$ \\
\hline \multicolumn{4}{|l|}{ Disease Characteristics } \\
\hline \begin{tabular}{|l} 
Stage \\
IA \\
IB \\
II \\
III \\
IV
\end{tabular} & $\begin{array}{c}49.00 \\
28.00 \\
13.00 \\
7.00 \\
5.00\end{array}$ & $\begin{array}{c}21.84-76.16 \\
8.43-47.57 \\
11.89-14.11 \\
4.48-9.52 \\
0.00-13.58\end{array}$ & \\
\hline \begin{tabular}{|l|} 
Histotype \\
Epithelial \\
Sarcomatoid \\
Biphasic \\
Desmoplastic \\
\end{tabular} & $\begin{array}{c}15.00 \\
2.00 \\
8.00 \\
10.00\end{array}$ & $\begin{array}{c}12.05-17.95 \\
1.12-2.81 \\
0.00-16.47\end{array}$ & 0.001 \\
\hline $\begin{array}{c}\text { Lymph Node } \\
\text { N+ } \\
\text { N0 } \\
\end{array}$ & $\begin{array}{l}12.00 \\
21.00\end{array}$ & $\begin{array}{c}8.25-15.74 \\
14.83-28.94\end{array}$ & 0,005 \\
\hline \multicolumn{4}{|l|}{ Clinical Characteristics } \\
\hline $\begin{array}{l}\begin{array}{l}\text { Neutrophil-to-Lymphocite Ratio } \\
\text { (NLR) } \\
\text { NLR }<3 \\
\text { NLR }<5 \\
\text { NLR }>5\end{array}\end{array}$ & $\begin{array}{c}22.00 \\
16.00 \\
8.00\end{array}$ & $\begin{array}{c}16.54-27.45 \\
12.42-19.44 \\
6.35-9.52\end{array}$ & $\begin{array}{l}0.001 \\
0.005\end{array}$ \\
\hline \multicolumn{4}{|l|}{ Treatment strategy } \\
\hline $\begin{array}{l}\text { Radical surgery } \\
\text { Extrapleural pneumonectomy, } \\
\text { total pleurectomy/decortication }\end{array}$ & 22.50 & $15.55-29.53$ & \\
\hline $\begin{array}{l}\text { Palliative surgery } \\
\text { Partial pleurectomy/ } \\
\text { decortication, pulmonary wedge } \\
\text { resections/lobectomy, } \\
\text { Pleural biopsy }\end{array}$ & 11.00 & $11.48-14.51$ & \\
\hline \begin{tabular}{|c|} 
EPP vs. P/D \\
EPP \\
P/D \\
\end{tabular} & $\begin{array}{l}13.00 \\
11.00\end{array}$ & $\begin{array}{l}9.77-16.22 \\
8.00-13.27\end{array}$ & 0.090 \\
\hline $\begin{array}{l}\text { EPP vs. EPP+HITOC } \\
\text { EPP } \\
\text { EPP+HITOC }\end{array}$ & $\begin{array}{l}13.00 \\
19.60\end{array}$ & $\begin{array}{c}9.77-16.22 \\
11.51-27.69\end{array}$ & \\
\hline
\end{tabular}

subtypes (15 months versus 2, 8 and 10 months respectively; $\mathrm{p}<0.001$ ) (Figure 3). The presence of an intrathoracic lymph node involvement (hilar or mediastinal) is a decisive staging parameter. Infact, $\mathrm{N}+$ disease (N1, N2 or N3) correlated with a median survival of 12 months $(95 \%$ CI 8.25 to 15.74), while N0 one with a median of 21 months (95\% CI 14.83 to 28.94). Neutrophil-to-Lymphocyte Ratio (NLR) was defined as the absolute neutrophil count divided by the absolute lymphocyte count. Although recent reports [26-28] in the Literature indicate that a NLR more than 5 can be considered high, Authors decided to review this cut-off bringing it to a nominal value of 3 in order to understaging them and to evaluate any difference from $\mathrm{NLR}<3$ patients and NLR $<5$ patients in terms of survival. According to this procedure, general population was clustered.

Patients with NLR $<3$ showed a median overall survival of 22 months (95\% CI 16.54-27.45), while $3<\mathrm{NLR}<5$ and NLR $>5$ ones had a poorer survival rate (12 and 8 months respectively) (Figure 4 ). In a bivariate analysis between these groups according to survival rates, a strong correlation between patients with inflammation index less than three and overall survival was evidenced $(p<0.001)$. It was noted the same result, although with lesser statistical significance, among patients with NLR $<5$ and survival $(p<0.005)$. Therefore, it can be argued the absolute ratio between neutrophil and lymphocytes may be considered an independent prognostic index in patients with malignant pleural mesothelioma. By dividing the population according to the surgical therapeutic strategy (e.g. radical and palliative surgery), in the first group (extrapleural pneumonectomy, total pleurectomy/decortication) it was noted a median survival of 22.5 months (95\% CI 15.55-29.53), as opposed to the group that underwent palliative surgery, due to the extension of the disease and/or poor performance status, where a median survival of 11 months (95\% CI 11.48-14.51) was assessed.

Patients who undergone to extrapleural pneumonectomy (EPP) had a median overall survival of 13 months compared to that of pleurectomy/decortication alone (11 months). No statistical differences were noted between this two procedures $(\mathrm{p}=0.09)$, although EPP present higher perioperative morbidity rates than pleurectomy $(21.8 \% v s .9 .3 \%)$. Finally, we evaluated the role of the intraoperative intrathoracic chemotherapy (HITOC) in patients amenable to radical surgery. Median survival rates in patients undergoing EPP and

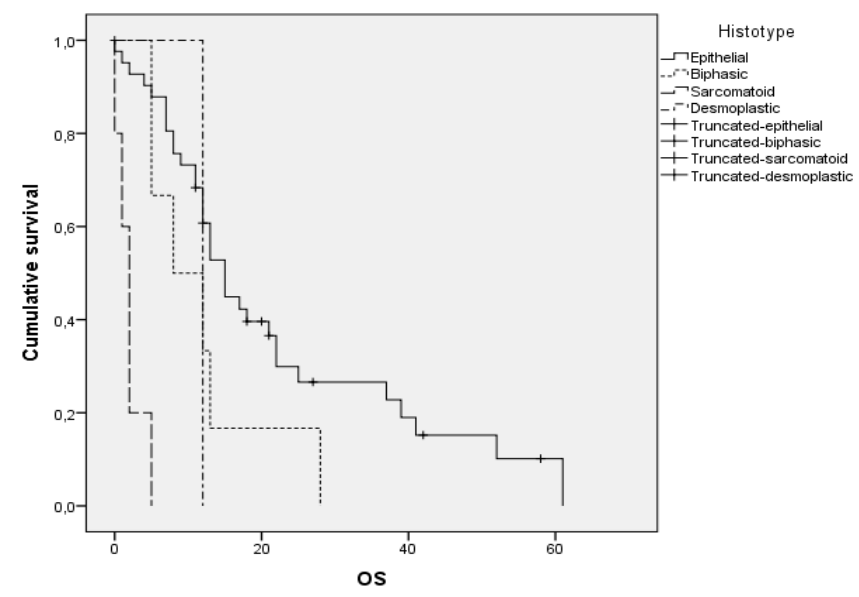

Figure 3. Overall survival according to histological pattern.

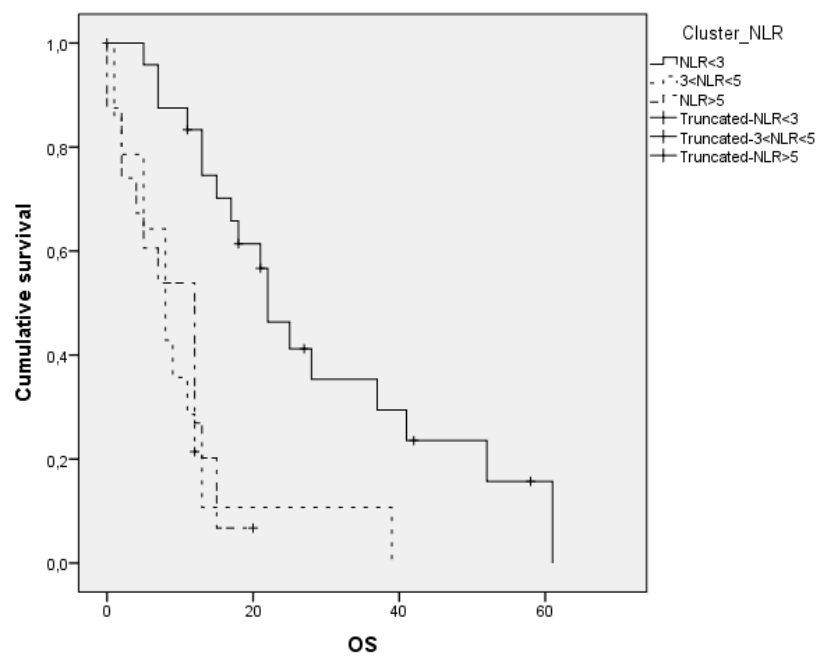

Figure 4. Overall survival according to Neutrophil-to- Lymphocite Ratio clusters. 
EPP+HITOC were 13 months (95\% CI 9.77-16.22) and $19.6(95 \%$ CI 11.51-27.69), respectively $(\mathrm{p}<0.005)$. Therefore, it can be argued that, although burdened by higher morbidity rates $(25.2 \%$ vs. $17.6 \%)$, HITOC is a valid complimentary surgical strategy for patients with malignant pleural mesothelioma and amenable for major surgery.

\section{Discussion}

Cancer is the leading cause of disease worldwide with 14.1 million of new cancer cases diagnosed in 2012 and it remains the leading cause of death with 8.2 million cancer deaths recorded in the same year [29]. Malignant pleural mesothelioma (MPM) is an aggressive cancer arising from mesothelial surfaces such as pleura (65\%-70\%), peritoneum (30\%), tunica vaginalis testis, and pericardium (1\%-2\%) [30].

MPM is a rare cancer, difficult to treat and commonly associated with environmental or occupational exposure to asbestos [31]. It is subtyped into three main forms according to the histological pattern (epithelial, sarcomatoid and biphasic), thought other patterns, such as desmoplastic, are known [16]. Prognosis is poor and dismal [32].

In Europe the incidence is 20 cases per million, but this value presents a high variability between different nations [33]. It recognizes a high latency and tumor initiation time; infact, as reported by the Italian Registry of Mesothelioma (ReNaM Study Group), the latency period between exposure to asbestos and the onset of the disease is about 44 years [34]. In Literature latency periods of less than 10 years are very rare. Some Authors report that a prolonged latency can be attributed to a less heavy exposure, recognizing a direct correlation between the amount of asbestos exposure and the onset of pleural mesothelioma [35]. Data still remain controversial [36].

MPM is considered an asbestos-related disease (ARD); in fact, pathophysiological processes are common to professional pneumoconiosis such as chronic inflammation resulting in pleural plaque formation due to asbestos fiber retention [37], promoting proinflammatory effects [38-40] and genotoxicity [41-43].

It is now widely recognized the outcome of cancer patients is not only determined by tumor, but also by interactions between the tumor and patient-related factors (age, sex, health status, comorbidities, microenvironment, genetic) [44]. In this regard, the role of inflammation and cytokine interaction between tumor and naive cells was investigated. These studies have demonstrated the critical role of inflammation $[45,46]$. In particular host response has been recognized as an independent prognostic factor in many tumors. Although the mechanisms seem still unclear, many inflammatory processes influencing important patient-related factors such as nutritional status, functional, performance status and immunological decline have been dimonstrated $[47,48]$. Moreover, protracted inflammation alters the balance [49] and activation of proliferative cellular pathways [23,50] perpetuating oncogenic stimuli. The neutrophil-to-lymphocyte ratio (NLR) is recognized as an independent prognostic factor in many cancers [51-53], although in Literature, opinions are conflicting (heterogeneity of populations, heterogeneity of cancer, chemotherapy).

A prognostic role for NLR in patients with Malignant Pleural Mesothelioma has been reported in a number of series, which are summarized in Table 4.

In 2010, Kao SC et al. [18] in a retrospective series of 173 MPM patients, showed NLR was an independent predictor for poor overall survival in such patients and that this index could stratify patients groups with survival difference. In our study, we confirm this trend clustering the population according to NLR. As reported by Guthrie et al. [54], in a meta-analysis conducted on 37,000 patients and more than 60 studies, a prognostic value of NLR was noted in 42 of them (nonrandomized cohorts, operable patients, patients receiving neoadjuvant, adjuvant and inoperable patients).

Five studies [18,55-58], comprising 1113 patients, reported the prognostic value of the NLR in patients with primary thoracic tumors. In these patients, NLR had a prognostic value for both disease-free interval for and overall survival. The analysis also showed how the index tendency during the medical therapy presented a prognostic value. In fact, the normalization of the NLR, as expressed in the studies by Cedres, was predictive of improved survival.

For malignant pleural mesothelioma, data in the literature are conflicting. Meniawy TM et al. [12] reported that in 321 patients with malignant pleural mesothelioma, CALGB and EORTC models but not NLR had prognostic value.

In our study, although it is a limited 54 patients non randomized cohort one, we noted an independent prognostic value of NLR. Our retrospective study included a mixed cohort of patients clustered by age, histology, exposure to asbestos and therapeutic strategy. Tumor staging was performed according to the AJCC's staging system. The descriptive analysis of the clinical and therapeutic characteristics recorded has highlighted significant correlations between epithelial subtype, absence of nodal involvement (N0 disease) and overall survival.

We have adopted an absolute threshold of NLR lower than that reported in Literature $(\mathrm{NLR}<3)$ in order to highlight significant differences by understaging these patients. In our experience, there is a survival advantage in patients with suboptimal index values rather than those with high values. We believe that a low ratio is an expression of a lower host immune response and therefore it prevents the onset of clinical features of chronic inflammation (fever, dysproteinaemia,

Table 4. Prognostic value of NLR in MPM patients.

\begin{tabular}{|c|c|c|c|c|c|}
\hline Study & Centre & Tumor & $\mathbf{N}$ & p-value & NLR threshold \\
\hline Linton A. (2014) [59] & Sydney (AUS) & MPM & 919 & $<0.001$ & 5 \\
\hline Clive AO (2014) [60] & Bristol (UK) & MPM & $\begin{array}{c}67 / 83 \\
\text { (UK Cohort 2) }\end{array}$ & $<0.001$ & 5 \\
\hline Abakay O (2014) [61] & Diyarbakir (TUR) & MPM & 155 & $<0.001$ & 3 \\
\hline Anevlavis S (2014) [62] & Alexandroupolis (GR) & MPM & 90 & 0.002 & continuous \\
\hline Kao SC (2013) [19] & Sydney (AUS) & MPM & 148 & 0.01 & 3 \\
\hline Pinato DL (2012) [21] & London (UK) & MPM & 171 & 0.0008 & continuous \\
\hline Kao SC (2011) [22] & Sydney (AUS) & MPM & 85 & $<0.01$ & 3 \\
\hline Kao SC (2010) [18] & Sydney (AUS) & MPM & 173 & $<0.001$ & 5 \\
\hline
\end{tabular}

MPM: Malignant Pleural Mesothelioma 
weight loss), factors definitely recognized as prognostically negative. At the same time, we do not think that NLR is a direct expression of the stage of the disease, as we have noted also in patients with advanced stage disease (stage III-IV), low values of the index were noted. In this case, we believe that in a metastatic patient, a low NLR could be an expression of the exhaustion of proinflammatory processes and of clinical manifestations related characteristics of the terminal disease.

\section{Conclusions}

In conclusion, we believe that the Neutrophil-to-Lymphocyte Ratio can be an independent, easily reproducibile and comparable prognostic index in patients with malignant pleural mesothelioma. We hope future prospective studies about it in order to validate a universally shared decision.

\section{Compliance with ethical standards}

The authors have no conflict of interest to be disclosed. The article is in accordance with ethical standards. The article does not contain any studies with human participants performed by the authors. For this type of study, no formal consent is not required. It is an anonymous study referring only to clinical data.

\section{References}

1. Kao SC, Reid G, Lee K, Vardy J, Clarke S, et al. (2010) Malignant mesothelioma. Intern Med J 40: 742-750. [Crossref]

2. Froudarakis ME (2012) Pleural diseases in the molecular era - time for more answers: introduction. Respiration 83: 2-4. [Crossref]

3. Linton A, Vardy J, Clarke S, van Zandwijk N (2012) The ticking time-bomb of asbestos: its insidious role in the development of malignant mesothelioma. Crit Rev Oncol Hematol 84: 200-212. [Crossref]

4. Tanrikulu AC, Abakay A, Kaplan MA, Küçüköner M, Palanci Y, et al. (2010) A clinical, radiographic and laboratory evaluation of prognostic factors in 363 patients with malignant pleural mesothelioma. Respiration 80: 480-487. [Crossref]

5. Vogelzang NJ (1992) Malignant mesothelioma: diagnostic and management strategies for 1992. Semin Oncol 19: 64-71. [Crossref]

6. Schouwink H, Korse CM, Bonfrer JM, Hart AA, Baas P (1999) Prognostic value of the serum tumour markers Cyfra 21-1 and tissue polypeptide antigen in malignant mesothelioma. Lung Cancer 25: 25-32. [Crossref]

7. Vogelzang NJ, Rusthoven JJ, Symanowski J, Denham C, Kaukel E, et al. (2003) Phase III study of pemetrexed in combination with cisplatin versus cisplatin alone in patients with malignant pleural mesothelioma. J Clin Oncol 21: 2636-2644. [Crossref]

8. Helland $\AA$, Solberg S, Brustugun OT (2012) Incidence and survival of malignant pleural mesothelioma in norway: a population-based study of 1686 cases. $J$ Thorac Oncol 7: 1858-1861. [Crossref]

9. Curran D, Sahmoud T, Therasse P, van Meerbeeck J, Postmus PE, et al. (1998) Prognostic factors in patients with pleural mesothelioma: the European Organization for Research and Treatment of Cancer experience. J Clin Oncol 16: 145-152. [Crossref]

10. Herndon JE, Green MR, Chahinian AP, Corson JM, Suzuki Y, et al. (1998) Factors predictive of survival among 337 patients with mesothelioma treated between 1984 and 1994 by the Cancer and Leukemia Group B. Chest 113: 723-731. [Crossref]

11. Fennell DA, Parmar A, Shamash J, Evans MT, Sheaff MT,et al.(2005) Statistical validation of the EORTC prognostic model for malignant pleural mesothelioma based on three consecutive phase II trials. J Clin Oncol 23: 184-189. [Crossref]

12. Meniawy TM, Creaney J, Lake RA, Nowak AK (2013) Existing models, but not neutrophil-to-lymphocyte ratio, are prognostic in malignant mesothelioma. $\mathrm{Br} J$ Cancer 109: 1813-1820. [Crossref]

13. Hillegass JM, Shukla A, Lathrop SA, MacPherson MB, Beuschel SL, et al. (2010) Inflammation precedes the development of human malignant mesotheliomas in a SCID mouse xenograft model. Ann N Y Acad Sci 1203: 7-14. [Crossref]

14. Nowak AK, Stockler MR, Byrne MJ(2004) Assessing quality of life during chemotherapy for pleural mesothelioma: Feasibility, validity, and results of using the European organization for research and treatment of cancer core quality of life questionnaire and lung cancer module. J Clin Oncol 22: 3172-3180. [Crossref]

15. Robinson BW, Lake RA (2005) Advances in malignant mesothelioma. $N$ Engl J Med 353: 1591-1603. [Crossref]

16. Robinson BW, Musk AW, Lake RA (2005) Malignant mesothelioma. Lancet 366: 397 408. [Crossref]

17. Robinson BM (2012) Malignant pleural mesothelioma: an epidemiological perspective Ann Cardiothorac Surg 1: 491-496. [Crossref]

18. Kao SC, Pavlakis N, Harvie R, Vardy JL, Boyer MJ, et al.(2010) High Blood Neutrophilto-Lymphocyte Ratio Is an Indicator of Poor Prognosis in Malignant Mesothelioma Patients Undergoing Systemic Therapy. Clin Cancer Res 16: 5805-5813. [Crossref]

19. Kao SC, Vardy J, Chatfield M, Corte P, Pavlakis N, et al. (2013) Validation of Prognostic Factors in Malignant Pleural Mesothelioma: A Retrospective Analysis of Data from Patients Seeking Compensation from the New South Wales Dust Diseases Board. Clin Lung Cancer 14: 70-77. [Crossref]

20. Kao SC, Clarke S, Vardy J, Corte P, Clarke C, et al. (2013) Patterns of care for malignant pleural mesothelioma patients compensated by the Dust Diseases Board in New South Wales, Australia. Intern Med J 43: 402-410. [Crossref]

21. Pinato DJ, Mauri FA, Ramakrishnan R, Wahab L, Lloyd T, et al. (2012) Inflammationbased prognostic indices in malignant pleural mesothelioma. J Thorac Oncol 7: 587594. [Crossref]

22. Kao SC1, Klebe S, Henderson DW, Reid G, Chatfield M, et al. (2011) Low calretinin expression and high neutrophil-to-lymphocyte ratio are poor prognostic factors in patients with malignant mesothelioma undergoing extrapleuralpneumonectomy. $J$ Thorac Oncol 6: 1923-1929. [Crossref]

23. Cedrés S, Montero MA, Martinez P, Martinez A, Rodríguez-Freixinós V, et al. (2012) Exploratory analysis of activation of PTEN-PI3K pathway and downstream proteins in malignant pleural mesothelioma (MPM). Lung Cancer 77: 192-198. [Crossref]

24. Suzuki K, Kadota K, Sima CS, Sadelain M, Rusch VW, et al. (2011) Chronic inflammation in tumorstroma is an independent predictor of prolonged survival in epithelioid malignant pleural mesothelioma patients. Cancer Immunol Immunother 60 1721-1728. [Crossref]

25. Edge SB, Byrd DR, Compton CC, Fritz AG, Greene FL, et al. (2010) Pleura mesothelioma, in AJCC Cancer Staging Manual, Springer-Verlag: New York.

26. Walsh SR, Cook EJ, Goulder F, Justin TA, Keeling NJ (2005) Neutrophil-lymphocyte ratio as a prognostic factor in colorectal cancer. J Surg Oncol 91: 181-184. [Crossref]

27. Kishi Y, Kopetz S, Chun YS, Palavecino M, Abdalla EK, et al. (2009) Blood Neutrophilto-Lymphocyte Ratio Predicts Survival in Patients with Colorectal Liver Metastases Treated with Systemic Chemotherapy. Ann Surg Oncol 16: 614-622. [Crossref]

28. Gomez D, Morris-Stiff G, Toogood GJ, Lodge JP, Prasad KR (2008) Impact of systemic inflammation on outcome following resection for intrahepatic cholangiocarcinoma. $J$ Surg Oncol 97: 513-518. [Crossref]

29. Chen JG, Chen WQ, Zhang SW, Zheng RS, Zhu J, et al. (2012) Incidence and mortality of liver cancer in China: an analysis on data from the National Registration System between 2003 and 2007. Zhonghua Liu Xing Bing Xue Za Zhi 33: 547-553. [Crossref]

30. Boffetta P (2007) Epidemiology of peritoneal mesothelioma: a review. Ann Oncol 18 985-990. [Crossref]

31. Park EK, Takahashi K, Hoshuyama T, Cheng TJ, Delgermaa V, et al. (2011) Global magnitude of reported and unreported mesothelioma. Environ Health Perspect 119 514-518. [Crossref]

32. Becklake MR, Bagatin E, Neder JA (2007) Asbestos-related diseases of the lungs and pleura: uses, trends and management over the last century. Int $J$ Tuberc Lung Dis 11: 356-369. [Crossref]

33. Lianes P, Remon J, Bover I, Isla D (2011) SEOM guidelines for the treatment of malignant pleural mesothelioma. Clin Transl Oncol 13: 569-573. [Crossref]

34. Marinaccio A, Binazzi A, Cauzillo G, Cavone D, Zotti RD, et al. (2007) Analysis of latency time and its determinants in asbestos related malignant mesothelioma cases of the Italian register. Eur J Cancer 43: 2722-2728. [Crossref]

35. Yeung P, Rogers A, Johnson A (1999) Distribution of mesothelioma cases in different occupational groups and industries in Australia, 1979-1995. Appl Occup Environ Hyg 14: 759-767. [Crossref]

36. Burdorf A, Dahhan M, Swuste P (2003) Occupational characteristics of cases with asbestos-related diseases in The Netherlands. Ann Occup Hyg 47: 485-492. [Crossref] 
37. Donaldson K, Murphy FA, Duffin R, Poland CA(2010) Asbestos, carbon nanotubes and the pleural mesothelium: a review of the hypothesis regarding the role of long fibre retention in the parietal pleura, inflammation and mesothelioma. Part Fibre Toxicol 7 : 5. [Crossref]

38. Yang H, Testa JR, Carbone M(2008) Mesothelioma Epidemiology, Carcinogenesis, and Pathogenesis. Curr Treat Options Oncol 9: 147-157. [Crossref]

39. Yang H, Bocchetta M, Kroczynska B, Elmishad AG, Chen Y, et al. (2006) TNF-alpha inhibits asbestos-induced cytotoxicity via a NF-kappaB-dependent pathway, a possible mechanism for asbestos-induced oncogenesis. Proc Natl Acad Sci U S A 103: $10397-$ 10402. [Crossref]

40. Choe N, Tanaka S, Xia W, Hemenway DR, Roggli VL, et al. (1997) Pleural macrophage recruitment and activation in asbestos-induced pleural injury. Environ Health Perspect 105: 1257-1260. [Crossref]

41. Puhakka A, Ollikainen T, Soini Y, Kahlos K, Säily M, et al. (2002) Modulation of DNA single-strand breaks by intracellular glutathione in human lung cells exposed to asbestos fibers. Mutat Res 514: 7-17. [Crossref]

42. Xu A, Zhou H, Yu DZ, Hei TK (2002) Mechanisms of the genotoxicity of crocidolite asbestos in mammalian cells: implication from mutation patterns induced by reactive oxygen species. Environ Health Perspect 110: 1003-1008. [Crossref]

43. Shukla A, Gulumian M, Hei TK, Kamp D, Rahman Q, et al. (2003) Multiple roles of oxidants in the pathogenesis of asbestos-induced diseases. Free Radic Biol Med 34: 1117-1129. [Crossref]

44. Tanrikulu AC, Hocanli I, Yilmaz A, Meteroglu F, Taylan M, et al.(2015) The Value of New Inflammatory Parameters in Malignant Mesothelioma Prognosis. Acta Medica Mediterranea 31: 9-15.

45. Hanahan D, Weinberg RA (2000) The hallmarks of cancer. Cell 100: 57-70. [Crossref]

46. Hanahan D, Weinberg RA (2011) Hallmarks of cancer: the next generation. Cell 144: 646-674. [Crossref]

47. Proctor MJ, McMillan DC, Morrison DS, Fletcher CD, Horgan PG, et al. (2012) A derived neutrophil to lymphocyte ratio predicts survival in patients with cancer. $\mathrm{Br} J$ Cancer 107: 695-699. [Crossref]

48. McMillan DC (2009) Systemic inflammation, nutritional status and survival in patients with cancer. Curr Opin Clin Nutr Metab Care 12: 223-226. [Crossref]

49. Hegmans JP, Hemmes A, Hammad H, Boon L, Hoogsteden HC, et al. (2006) Mesothelioma environment comprises cytokines and T-regulatory cells that suppress immune responses. Eur Respir J 27: 1086-1095. [Crossref]

50. Cedrés S, Montero MA, Zamora E, Martínez A, Martínez P, et al. (2014) Expression of Wilms' tumor gene (WT1) is associated with survival in malignant pleural mesothelioma. Clin Transl Oncol 16: 776-782. [Crossref]

51. Roxburgh CS, McMillan DC (2010) Role of systemic inflammatory response in predicting survival in patients with primary operable cancer. Future Oncol 6: 149-163. [Crossref]

52. Gabay C, Kushner I (1999) Acute-phase proteins and other systemic responses to inflammation. $N$ Engl J Med 340: 448-454. [Crossref]

53. Clarke SJ, Chua W, Moore M, Kao S, Phan V, et al. (2011) Use of inflammatory markers to guide cancer treatment. Clin Pharmacol Ther 90: 475-478. [Crossref]

54. Guthrie GJ, Charles KA, Roxburgh CS, Horgan PG, McMillan DC, et al. (2013) The systemic inflammation-based neutrophil-lymphocyte ratio: experience in patients with cancer. Crit Rev Oncol Hematol 88: 218-230. [Crossref]

55. Cedrés S, Torrejon D, Martínez A, Martinez P, Navarro A, et al. (2012) Neutrophil to lymphocyte ratio (NLR) as an indicator of poor prognosis in stage IV non-small cell lung cancer. Clin Transl Oncol 14: 864-869. [Crossref]

56. Yao Y, Yuan D, Liu H, Gu X, Song Y (2013)Pretreatment neutrophil to lymphocyte ratio is associated with response to therapy and prognosis of advanced non-small cell lung cancer patients treated with first-line platinum-based chemotherapy. Cancer Immunol Immunother 62: 471-479. [Crossref]

57. Lee Y, Kim SH, Han JY, Kim HT, Yun T, et al. (2012) Early neutrophil-to-lymphocyte ratio reduction as a surrogate marker of prognosis in never smokers with advanced lung adenocarcinoma receiving gefitinib or standard chemotherapy as first-line therapy. $J$ Cancer Res Clin Oncol 138: 2009-2016. [Crossref]

58. Teramukai S, Kitano T, Kishida Y, Kawahara M, Kubota K, et al.(2009) Pretreatment neutrophil count as an independent prognostic factor in advanced non-small-cell lung cancer: An analysis of Japan Multinational Trial Organisation LC00-03. Eur J Cancer 45: 1950-1958. [Crossref]

59. Linton A, Pavlakis N, O'Connell R, Soeberg M, Kao S, et al.(2014) Factors associated with survival in a large series of patients with malignant pleural mesothelioma in New South Wales. Br J Cancer 111: 1860-1869. [Crossref]

60. Clive AO, Kahan BC, Hooper CE, Bhatnagar R, Morley AJ, et al. (2014) Predicting survival in malignant pleural effusion: development and validation of the LENT prognostic score. Thorax 69: 1098-1104. [Crossref]

61. Abakay O, Tanrikulu AC, Palanci Y, Abakay A (2014) The value of inflammatory parameters in the prognosis of malignant mesothelioma. J Int Med Res 42: 554-565. [Crossref]

62. Anevlavis S, Kouliatsis G, Sotiriou I, Koukourakis MI, Archontogeorgis K, et al. (2014) Prognostic factors in patients presenting with pleural effusion revealing malignancy. Respiration 87: 311-316. [Crossref]

Copyright: (C) 2015 Mucilli F. This is an open-access article distributed under the terms of the Creative Commons Attribution License, which permits unrestricted use, distribution, and reproduction in any medium, provided the original author and source are credited. 